\title{
Retraction Note: Regional differences in the surface temperature of naked neck laying hens in a semi-arid environment
}

\author{
João Batista Freire de Souza Jr • \\ Alex Martins Varela de Arruda • \\ Hérica Girlane Tertulino Domingos • \\ Leonardo Lelis de Macedo Costa
}

Published online: 6 August 2014

(C) ISB 2014

\section{Retraction to: Int J Biometeorol}

DOI 10.1007/s00484-012-0561-7

This article published in Volume 57, Issue 3, DOI 10.1007/ s00484-012-0561-7 has been retracted at the request of the Editor-in-Chief and co-Editors, as it contains portions of other authors' writings on the same topic without sufficient attribution to these earlier works being given. The principal author of the paper acknowledged that text from background sources was used without proper reference to the original source, specifically several pages from the Master's Dissertation entitled, 'Determinação do balanço de calor em frangos de corte por meio das temperaturas corporais' authored by Sheila Tavares Nascimento, São Paulo State University, Brazil.

The online version of the original article can be found at http://dx.doi.org/ 10.1007/s00484-012-0561-7.

J. B. F. de Souza Jr $(\bowtie) \cdot$ A. M. V. de Arruda • H. G. T. Domingos •

L. L. de Macedo Costa

Department of Animal Sciences,

Universidade Federal Rural do Semi-Árido (UFERSA),

Mossoró, RN, Brazil

e-mail: jb_zootecnista@hotmail.com 